\title{
Citrullinemia, Report of a Case, with Studies on Antenatal Diagnosis
}

\author{
F. H. Roerdink and W. L. M. Gouw \\ Department of Human Genetics
}

A. Okken, J. F. van der Blij, G. Luit-de Haan, and F. A. Hommes ${ }^{[32]}$

Department of Pediatrics

H. J. Huisjes

Department of Obstetrics, University of Groningen, School of Medicine, Groningen, The Netherlands

\section{Extract}

A case is described of an infant with a deficiency of liver argininosuccinate synthetase, characterized by rapidly increasing drowsiness, respiratory insufficiency, and convulsions starting $67 \mathrm{hr}$ after birth, which resulted in the death of the patient on the 4th day.

Quantitative analyses of amino acids in blood plasma showed increased concentrations of citrulline $(2.64 \mathrm{~mm})$ lysine $(1.25 \mathrm{~mm})$, histidine $(0.34 \mathrm{~mm})$, glutamine $(4.17 \mathrm{~mm})$, proline $(1.67 \mathrm{~mm})$, glycine $(1.35 \mathrm{~mm})$, alanine $(3.96 \mathrm{~mm})$, and methionine $(0.24 \mathrm{~mm})$.

The activity of argininosuccinate synthetase in a liver biopsy was found to be below the limits of detection, whereas the activities of carbamylphosphate synthetase and ornithine transcarbamylase (21.8 and $55.6 \mu \mathrm{mol} / \mathrm{min} \times \mathrm{g}$ wet $\mathrm{wt}$, respectively) were higher than those of the control tissue.

The activity of arginase (141.1 $\mu \mathrm{mol} / \mathrm{min} \times \mathrm{g}$ wet $\mathrm{wt}$ ), an enzyme localized behind the enzymic block, was found to be lower than that of the controls $(230-800 \mu \mathrm{mol} /$ $\min \times \mathrm{g}$ wet $w \mathrm{t})$.

It is suggested that these differences are due to adaptation of urea cycle enzymes to protein intake as demonstrated by Nuzum and Snodgrass [14] in primates.

The activity of argininosuccinate synthetase of a postmortem brain biopsy was found to be normal. This points to a different genetic origin (isoenzyme) of the brain enzyme.

Cultured amniotic cells of a fetus from a pregnancy in the same family, taken in the 20th week of pregnancy, demonstrated incorporation of ureido- ${ }^{14} \mathrm{C}$-citrulline into trichloroacetic acid (TCA)-soluble material to an extent half of that observed with cultured amniotic cells from a normal fetus $(31 \mathrm{dpm} / \mu \mathrm{g}$ DNA and $68 \mathrm{dpm} / \mu \mathrm{g}$ DNA, respectively). This has been interpreted as being due to the heterozygotic state of the fetus.

After a normal pregnancy a healthy boy was born. 


\section{Speculation}

The metabolic basis for neurologic abnormalities in citrullinemia is not known. In the present case a virtual absence of argininosuccinate synthetase of liver was found, whereas the activity of the brain enzyme was normal. As the blood ammonia concentration was never found to be abnormal, it is postulated that citrulline itself is toxic, i.e., inhibitory to a biochemical reaction.

\section{Introduction}

Citrullinemia is probably the rarest inborn error of metabolism involving the urea cycle. Only six cases have been reported up till now [11-13, 21, 23-25, 26]. In three of these the initial development of the affected children was normal, the onset of symptoms taking place after some months of apparently normal growth and development. This course of the disease is in sharp contrast to that described by Van der Zee et al. [24], who found a rapidly increasing drowsiness, respiratory insufficiency, and convulsions a few days after birth, which resulted ultimately in an early death of their patient. A different case seems to be that described by Scott-Emuakpor et al. [21], in view of the alternate metabolic pathway for the disposal of ammonia.

We report here a seventh case of citrullinemia, namely of the type described by Van der Zee et al. [24]. In addition, the possibility for antenatal diagnosis was explored.

\section{Materials and Methods}

Quantitative amino acid analyses were performed by elution chromatography with a Beckman/Spinco Unichrom amino acid analyzer [27]. Blood pyruvate and lactate were determined enzymatically according to the methods of Bücher et al. [4] and Hohorst [9], respectively. Methylmalonic acid was assayed according to Oberholzer et al. [15]. Blood serum was screened for short chain fatty acids by the gas chromatographic method described by Tanaka et al. [22]. Blood ammonia was determined as described by Gips and WilkensAlberts [8]. The methods of Brown and Cohen [3] were used for the quantitative assay of urea cycle enzymes. Amniotic cells were obtained by transabdominal amniocentesis after localization of the placenta by echoscopy in the 20th week of pregnancy, after one failure at 16 weeks.

Normal control lines were obtained from a 3month-old embryo (skin biopsy) and from a 12-weekold embryo (amniotic cells). The citrullinemia cell line was obtained from the American Type Culture Collection, Rockville, Maryland, no. CCL 76 . This is a human skin citrullinemia fibroblast line, originally obtained and described by Tedesco and Mellman [23]. On arrival the cell line had gone through 12 cell passages. The expected viability was $85 \%$.

Amniotic fluid was centrifuged at $1,000 \mathrm{rpm}$ for 5 min. The pelleted cells were suspended in $0.5 \mathrm{ml}$ fetal calf serum and inoculated in Leighton tubes in which they were allowed to settle for the next $24 \mathrm{hr}$. Amniotic fluid cells and fetal skin fibroblasts were cultured in medium 199 with Earle's salts [28] supplemented with $20 \%$ fetal calf serum, $50 \mathrm{U}$ penicillin $/ \mathrm{ml}$ and $50 \mu \mathrm{g}$ streptomycin $/ \mathrm{ml}$. The tubes were gassed with $5 \% \mathrm{CO}_{2}$ in air and incubated at $37^{\circ}$. Medium was changed every 3 days.

Human skin citrullinemia fibroblasts were grown in 90\% (v/v) double strength Eagle's basal medium in Earle's balanced salt solution [29] and $10 \%(\mathrm{v} / \mathrm{v})$ fetal calf serum as described by Tedesco and Mellman [23]. Penicillin and streptomycin $(50 \mathrm{U} / \mathrm{ml}$ and $50 \mu \mathrm{g} / \mathrm{ml}$, respectively) were added to the medium. Cells were harvested or passed to the next culture after 3-5 min exposure to $0.15 \%$ trypsin in Ca- and Mg-free Hanks' solution.

Karyotyping of amniotic fluid cells was carried out on coverslip cultures. Examination of Y-bodies was performed by fluorescence microscopy after staining with an $0.5 \%$ aqueous solution of atebrin. Barr bodies were studied by staining with thionine.

Incorporation into TCA-insoluble cell material of arginine derived from ureido. ${ }^{14} \mathrm{C}$-citrulline [30] was measured as described by Tedesco and Mellman [23]. Radioactivity was counted with a Nuclear Chicago Mark I liquid scintillation counter [31] using Bray's solution as the scintillating fluid [2]. The TCA-insoluble material was solubilized with $0.1 \mathrm{ml}$ hyamin. DNA was determined as described by Schneider [19].

\section{Case Report}

At admittance the patient, a boy, was $84 \mathrm{hr}$ old. $\mathrm{He}$ was comatose and apnoic. He was the first child of 
Table I. Summary of biochemical data and treatment of the patient

\begin{tabular}{|c|c|c|c|c|c|c|c|c|c|}
\hline Age, hr & $\begin{array}{l}\mathrm{Na} \\
\mathrm{mm}\end{array}$ & $\mathrm{K}, \mathrm{mM}$ & $\mathrm{Ca}, \mathrm{ms}$ & $\mathrm{Cl}, \mathrm{ms}$ & $\begin{array}{l}\text { Urea, } \\
\text { mM }\end{array}$ & $\mathrm{pH}$ & $\underset{\mathrm{mm} \stackrel{\mathrm{P}_{\mathrm{H}}}{\mathrm{H} g}}{ }$ & $\begin{array}{c}\mathrm{PCO}_{2} \\
\mathrm{~mm} \mathrm{Hg}\end{array}$ & Treatment \\
\hline 84 & 145 & 6.3 & 1.65 & 105 & 3.0 & 7.21 & 46 & 42 & $\begin{array}{l}\text { Glucose infusion, } 10 \% \text {. Artificial respiration, } 5 \mathrm{ml} \\
\text { glucose, } 20 \%\end{array}$ \\
\hline 87 & & & & & & 7.06 & 43 & 44 & $27 \mathrm{mg} \mathrm{Ca}^{++} / 100 \% \mathrm{O}_{2}$ \\
\hline 87,5 & & & & & & & & & $8 \mathrm{mI} \mathrm{THAM,} 3.6 \%$ \\
\hline 91 & & & & & & 7.26 & 162 & 31 & \\
\hline 97 & & & & & & 7.40 & 146 & 22 & \\
\hline 103 & 136 & 5.7 & 1.5 & 105 & 4.7 & 7.47 & 127 & 17 & \\
\hline 108 & & & & & & 7.32 & 78 & 31 & \\
\hline 120 & 139 & 4.7 & 1.35 & 98 & 2.7 & & & & $27 \mathrm{mg} \mathrm{Ca}{ }^{++}$ \\
\hline 130 & & & & & & 6.93 & & & $8 \mathrm{ml}$ THAM, tube closed \\
\hline 139 & & & & & & 7.23 & & & $4 \mathrm{ml}$ THAM \\
\hline 141 & & & & & & 7.43 & 74 & 30 & \\
\hline 148 & 126 & 5.9 & 1.35 & 95 & 2.5 & 7.31 & 85 & 33 & $40 \mathrm{mg} \mathrm{Ca}^{++}$ \\
\hline
\end{tabular}

Table II. Amino acids of serum and urine of patient

\begin{tabular}{|c|c|c|c|c|}
\hline Amino acids & $\underset{\text { Control (serum }[7]),}{\text { my }}$ & $\begin{array}{l}\text { Serum at } \\
72 \mathrm{hr}, \mathrm{ms}\end{array}$ & $\begin{array}{l}\text { Serum at } \\
96 \mathrm{hr} \\
\mathbf{m s c}\end{array}$ & $\begin{array}{c}\text { Urine } \\
(96 \mathrm{hr}), \\
\text { my }\end{array}$ \\
\hline Ornithine & $0.15 \pm 0.03$ & 0.16 & 0.07 & \\
\hline Lysine & $0.24 \pm 0.08$ & 1.25 & 1.02 & 5.03 \\
\hline Histidine & $0.09 \pm 0.06$ & 0.34 & 0.43 & 2.99 \\
\hline Arginine & & 0.00 & 0.01 & \\
\hline Aspartic acid & & 0.13 & 0.04 & 0.27 \\
\hline Threonine & $0.17 \pm 0.06$ & 0.33 & 0.28 & 1.32 \\
\hline Serine & $0.18 \pm 0.09$ & 0.41 & 0.23 & 2.45 \\
\hline $\begin{array}{c}\text { Asparagine }+ \\
\text { glutamine }\end{array}$ & $0.67 \pm 0.02$ & 4.17 & 7.54 & 37.94 \\
\hline Proline & $0.29 \pm 0.06$ & 1.67 & 2.00 & 9.81 \\
\hline Glutamic acid & & 0.85 & 0.19 & \\
\hline Citrulline & $0.01 \pm 0.02$ & 2.64 & 2.75 & 22.61 \\
\hline Glycine & $0.24 \pm 0.08$ & 1.35 & 4.02 & 12.91 \\
\hline Alanine & $0.33 \pm 0.11$ & 3.96 & 0.38 & 11.27 \\
\hline Valine & $0.22 \pm 0.08$ & 0.48 & 0.38 & 0.74 \\
\hline Half-cystine & & & 0.06 & 0.31 \\
\hline Methionine & $0.01 \pm 0.02$ & 0.24 & 0.24 & 0.18 \\
\hline Isoleucine & $0.07 \pm 0.02$ & 0.16 & 0.08 & 0.04 \\
\hline Leucine & $0.14 \pm 0.04$ & 0.44 & 0.27 & 0.27 \\
\hline Tyrosine & $0.15 \pm 0.03$ & 0.52 & 0.50 & 1.46 \\
\hline Phenylalanine & $0.07 \pm 0.05$ & 0.25 & 0.22 & 0.75 \\
\hline
\end{tabular}

unrelated parents and was born after an uncomplicated second pregnancy of 40 weeks (birthweight 4,070 g). The first pregnancy had ended in spontaneous abortion 3 months after conception. The patient's first $67 \mathrm{hr}$ of life passed uneventfully. Breast-feeding was started after 24 hr. Irregular breathing with grunting and slight convulsions were noted $67 \mathrm{hr}$ after birth. Prolonged spells of apnea made intubation and artificial respiration necessary. During his stay in our hospital artificial respiration had to be maintained. There was a slight metabolic acidosis which was corrected by arterial administration of THAM-buffer. The child, however, remained apnoic and areflexic, and no im- provement in the clinical condition could be observed. Fluid was administered intravenously, no oral feeding being given. On the 4th day of life the EEG showed virtually no activity, and it was decided to stop artificial respiration. Shortly after, heart pulsation stopped. Before death the diagnosis of citrullinemia had been made.

A summary of routine laboratory investigations and treatment is given in Table I.

\section{Results}

\section{Biochemical Investigations Performed on Patient}

Preliminary screening by high voltage electrophoresis at $\mathrm{pH} 1.9$ of the patient's urine for amino acids demonstrated the presence of a large fraction just before and partly coinciding with glutamine. Subsequent quantitative assay of amino acids in blood and urine by column chromatography revealed a fraction which coincided with added citrulline.

Table II gives the results of these assays. A high concentration of citrulline of $2.75 \mathrm{~mm}$ was found. The concentration of this amino acid in plasma of normal infants is about $20 \mu \mathrm{M}$. As in the case described by Van der Zee et al. [24], increased levels of lysine, histidine, glutamine, proline, glycine, alanine, and methionine were also observed.

It was not possible to collect cerebrospinal fluid. No analyses of cerebrospinal fluid amino acids can therefore be presented.

In a search for the cause of the metabolic acidosis (see Table I) the urine was tested for methylmalonic acid, with a negative result. Screening [22] of serum for short chain fatty acids yielded a negative result likewise. At the age of $96 \mathrm{hr}$ blood lactate and pyru- 
Table III. Activities of urea cycle enzymes in liver and brain

\begin{tabular}{|c|c|c|c|c|}
\hline \multirow{3}{*}{ Enzyme } & \multicolumn{4}{|c|}{ Enzyme activity, $\mu \mathrm{mol} / \mathrm{min} / \mathrm{g}$ tissue, wet $\mathrm{wt}$} \\
\hline & \multirow{2}{*}{$\begin{array}{c}\text { Liver } \\
\text { patient }\end{array}$} & \multirow{2}{*}{$\begin{array}{c}\text { Brain } \\
\text { patient }\end{array}$} & \multicolumn{2}{|c|}{ Controls } \\
\hline & & & Liver & Brain \\
\hline $\begin{array}{l}\text { Carbamylphosphate } \\
\text { synthetase }\end{array}$ & 21.8 & & $0.60-0.90$ & 0.40 \\
\hline $\begin{array}{l}\text { Ornithinetranscar- } \\
\text { bamylase }\end{array}$ & 55.6 & 0.05 & $9.0-12.0$ & 3.45 \\
\hline $\begin{array}{l}\text { Argininosuccinate } \\
\text { synthetase }\end{array}$ & N.D. ${ }^{1}$ & 0.98 & $0.5-1.5$ & \\
\hline Arginase & 114.1 & 1.14 & $230-800$ & \\
\hline
\end{tabular}

${ }^{1}$ N.D. : not detectable.

vate levels were $3.06 \mathrm{~mm}$ and $0.14 \mathrm{~mm}$, respectively. Accumulation of lactic acid should therefore be held responsible for the metabolic acidosis.

At the age of $120 \mathrm{hr}$ the blood ammonia concentration was $45 \mu \mathrm{M}$, a value within the normal range.

A liver biopsy was performed at the age of $150 \mathrm{hr}$ for quantitative assay of urea cycle enzymes. Table III summarizes the results, as well as the data obtained on a postmortem brain biopsy.

The complete lack of activity of liver argininosuccinate synthetase is consistent with the high citrulline levels found in plasma and urine.

\section{Postmortem Examination}

At autopsy the lungs were found to be atelectatic with local hemorrhages in the lower segments. In the somewhat enlarged liver a slight fatty degeneration was noted. Other organs were found to be normal except for the brain which, on inspection, was found to be extremely soft. A detailed description of the morbid anatomy will be published elsewhere.

\section{Antenatal Diagnosis}

When the mother of propositus presented to the Department of Obstetrics for her third pregnancy it was decided to try to diagnose antenatally for a possible citrullinemia fetus. The pioneering work of Tedesco and Mellman [23] offered the possibility of testing amniotic cells for the capacity to incorporate arginine formed from citrulline into TCA-insoluble material, because fibroblast-like cells do not contain arginase [23]. Positive controls, i.e., cells from presumably noncitrullinemic fetuses, should give such an incorporation, whereas a negative control, i.e., cells from a proven citrullinemia patient, should give very little incorporation. The latter strain of cells has been used by Tedesco and Mellman [23] and is available from the American Type Culture Collection. This strain was used because cultured fibroblasts from the present case were not available. Both types of controls were incorporated in the present study. The results as well as those obtained from the present case are shown in Table IV. Amniocentesis was performed in the 20th week of pregnancy.

Karyotyping of the cultured amniotic cells of the present case and of the normal control amniotic cells showed them to be of male sex. After staining with atebrin, examination by fluorescence microscopy revealed 89 Y-bodies/ 100 cells in the present case and 91 Y-bodies/100 cells in the normal control amniotic cells. With the thionine staining, no Barr bodies were detectable in both cases. This verified that only fetal cells had been cultured and that no cells from the mother were present in the cell population.

Fibroblasts from a citrullinemic patient did give a very low incorporation into TCA-insoluble material, in contrast to cultured amniotic cells of a normal fetus. These controls demonstrated the adequacy of the applied technique. The cultured amniotic cells of the present case showed an incorporation of ureido${ }^{14} \mathrm{C}$-citrulline into TCA-insoluble cell material in between that of a normal control and a citrullinemic cell line. The possibility that this is due to a heterozygotic state of the present case cannot be excluded. It constituted, however, insufficient evidence to consider a therapeutic abortion.

After an uncomplicated pregnancy of 40 weeks a healthy boy was born. Blood citrulline levels were assayed every day during the first 5 days of life and at intervals of 3 days for the next 10 days. The patient received a normal formula with a protein intake of $2 \mathrm{~g} /$ $\mathrm{kg}$. Blood citrulline levels varied from $10-30 \mu \mathrm{M}$. Other blood animo acids were also within the normal range. Clinically the neonate was completely normal.

Table IV. Incorporation of ureido-14 C-citrulline into cell protein (trichloroacetic acid-insoluble material) by cultured amniotic fluid cells ${ }^{1}$

Cell line $\quad \begin{gathered}\text { Incorporation, } \\ \mathrm{dpm} / \mu \mathrm{DNNA}\end{gathered}$

Cultured amniotic cells normal, 12th week of 68 pregnancy

Citrullinemic fibroblasts ATCC no. CCL-76

Cultured fetal skin fibroblasts, normal, 13 th week of pregnancy

Cultured amniotic cells of present case, 20th week of pregnancy

\footnotetext{
1 For experimental conditions see the text.
} 


\section{Discussion}

The observation (Table I) that urea can be demonstrated in blood of this patient suggests that the urea cycle is not completely inoperative, despite the fact that the activity of argininosuccinate synthetase is below the limits of detection of the method used. Tedesco and Mellman [23] have demonstrated a 25-fold increased value of the $K_{m}$ for citrulline of argininosuccinate synthetase in a case of citrullinemia. The active center of the enzyme is apparently changed, which results in a lower affinity of the enzyme towards the substrate. Such a mutation of the enzyme at the binding site for citrulline may have occurred in the case described here as well, which would explain the levels of urea in blood.

The alternative pathway for the synthesis of urea, namely from lysine to homocitrulline through homoarginine to urea, as suggested by Scott-Emuakpor et al. [21], is unlikely to be operative in this case as no homocitrulline and/or homoarginine could be detected in plasma or urine.

It is noteworthy that arginiosuccinate synthetase activity could be demonstrated in brain. It is therefore likely that the brain enzyme is different from the liver enzyme. This would be the second example of an enzyme of the urea cycle in brain not being affected by a mutation, as Cathelineau et al. [5] showed recently that the $\mathrm{K}_{\mathrm{m}}$ for ornithine of liver ornithine transcarbamylase of a patient with hyperammonemia was increased by a factor of 100 as compared with the normal liver enzyme, whereas the brain enzyme showed a normal affinity for ornithine. A contribution of the brain to total urea production can, however, be neglected. The level of activity, as well as that of arginase, is of the same order of magnitude as that reported by Ratner et al. [18]. A defective utilization of citrulline in brain, a possibility raised by Colombo [6] as a possible cause of the neurologic symptoms, is therefore unlikely.

As this patient showed a normal blood ammonia concentration, ammonia intoxication as a cause of the clinical symptoms can also be excluded. This does not necessarily mean that ammonia intoxication cannot occur in this disease, because the patient did not receive protein since the moment of admission to the hospital. We suggest that citrulline itself is toxic, i.e., inhibitory, to an as yet unknown biochemical reaction. Preliminary experiments with slices of rat brain as well as with perfusion of whole rat brain have indicated that citrulline at a concentration of $3 \mathrm{~mm}$ inhibits glucose utilization and lactate production. Further research will, however, be needed to investigate this phenomenon and to discover whether it can indeed be held responsible for extensive brain damage or whether deficiency of product (arginine) contributes also to the brain damage.

Nuzum and Snodgrass [14] have demonstrated recently the adaptation of urea cycle enzymes to dietary protein intake in primates. In this connection it is interesting to note that carbamylphosphate synthetase and ornithine transcarbamylase in liver of this patient have a considerably higher activity than that found in control subjects, despite the limited protein intake of the patient.

Accumulation of substrate before the enzymic block may be responsible for this phenomenon. In agreement with this hypothesis is the observation that the activity of arginase, localized behind the enzymic block in the urea cycle, is lower than that of the control subjects. The enzyme activities observed in the present case are higher than those reported by Van der Zee $e t$ al. [24]. This difference may be due to the fact that material for enzyme studies of the latter case were stored at $-70^{\circ}$, whereas that of the present case was used immediately.

The diagnosis of citrullinemia, and especially of the variant with the fulminant course, seems to be firmly established in this patient. Although only a few cases of citrullinemia are known it is presumably an inborn error with an autosomal recessive mode of inheritance. It was therefore decided to diagnose the disease, if possible, before birth. The technique introduced by Tedesco and Mellman is also applicable to cultured amniotic cells, as Jacoby et al. [10] demonstrated the incorporation of label into TCA-insoluble material from ureido- ${ }^{14} \mathrm{C}$-citrulline in their studies on the antenatal diagnosis of argininosuccinuria. These observations have been confirmed in the present study (Table IV). The technique as such was adequate as the cell line derived from a citrullinemic patient did indeed show a virtually negligible incorporation. Cultured amniotic cells of the present case showed an incorporation in between that of a normal control subject and that of a citrullinemic patient. This is suggestive for a heterozygote.

On the other hand, the fact that incorporation was observed at all cannot be taken as conclusive evidence that the child to be born is healthy or at least heterozygotic. It may be that the type of cells selected for analysis (it is the only type of fetal cell which can be obtained rather easily) is not well chosen because the genetic defect does not present itself in this type of 
cell. Examples of this phenomenon are available: Scott et al. [20] demonstrated the presence of the enzymes of glycine catabolism in cultured skin fibroblasts of a nonketotic hyperglycinemic patient. Amniotic cells, being predominantly of ectodermal origin, may be different from the citrullinemic fibroblasts which have been used as the negative control in the present study. A special reason to be cautious in this case is the fact that, in a younger sibling, liver argininosuccinate synthetase deficiency had been demonstrated; however, the activity of this enzyme in brain was normal, which demonstrated the presence of isoenzymes in different tissues.

The diagnosis of citrullinemia can therefore only be made before birth, provided that a correlation has been established between lack of incorporation into TCA-insoluble material by cultured amniotic cells and the absence of liver argininosuccinate synthetase, which is already present in human fetal liver at the stage of development the amniotic cells are collected [17].

\section{Summary}

A case is described of an infant with a deficiency of liver argininosuccinate synthetase, characterized by rapidly increasing drowsiness, respiratory insufficiency, and convulsions starting $67 \mathrm{hr}$ after birth, which resulted in death of the patient on the 4th day.

Quantitative analyses of amino acids of blood plasma also revealed increased concentrations of citrulline and elevated levels of lysine, histidine, glutamine, proline, glycine, alanine, and methionine.

A liver biopsy demonstrated the absence of argininosuccinate synthetase activity, although the activity of carbamylphosphate synthetase and ornithinetranscarbamylase were well above normal activity levels. In contrast to these enzymes localized in the urea cycle before the enzymic block, the activity of arginase, localized behind the enzymic block, was found to be lower. The activity of argininosuccinate synthetase of a postmortem brain biopsy was found to be normal.

Cultured amniotic cells of a fetus from a pregnancy in the same family taken in the 20th week of pregnancy demonstrated incorporation of ureido ${ }^{14} \mathrm{C}$-citrulline into TCA-insoluble cell material. The extent of incor1 oration was half of that observed with cultured amniotic cells from a normal fetus. It is suggested that this is due to the heterozygotic state of the fetus.

\section{References and Notes}

1. Baumgartner, R., Ando, T., and Nyhan, W. L.: Nonketotic hyperglycinemia. J. Pediat., 77: 164 (1970).

2. BrAY, G. A.: A simple efficient liquid scintillator for counting aqueous solutions in a liquid scintillation counter. Anal. Biochem., 1: 279 (1960).

3. Brown, G. W., JR., AND Cohen, P. P.: Comparative biochemistry of urea synthesis. I. Methods for the quantitative assay of urea cycle enzymes in liver. J. Biol. Chem., 234: 1769 (1959).

4. Bücher, T., CzAK, R., LAMPRECHT, W., ANd LATZKo, E.: In: H. U. Bergmeyer: Methods of Enzymatic Analysis, p. 253 (Academic Press, New York, 1965).

5. Cathelineau, L., Saudubray, J. M., and Polonovsky, C.: Ornithine carbamyl transferase: The effects of $\mathrm{pH}$ on the kinetics of a mutant human enzyme. Clin. Chem. Acta, 41: 305 (1972).

6. Соцомво, J. P.: Congenital Disorders of the Urea Cycle and Ammonia Detoxication, p. 81 (S. Karger, Basel, 1971).

7. Ghadimi, H., and Pecora, H.: Plasma amino acids after birth. Pediatrics, 34: 82 (1964).

8. Gips, H. G., ANd Wilkens-Alberts, M.: Ammonia determination in blood, using the TCA direct method. Clin. Chim. Acta, 22: 183 (1968).

9. Hohorst, H. J. In: H. U. Bergmeyer: Methods of Enzymatic Analysis, p. 266 (Academic Press, New York, 1965).

10. Jacoby, L. B., Littlefield, J. W., Milanski, A., Shil, V. E., AND Wibray, R. S., JR.: A micro-assay for argininosuccinase in cultured cells. Amer. J. Hum. Genet., 2t: $32 \mathrm{I}$ (1972).

11. McMurray, W. C., Mohyaddin, F., Rossiter, R. J., Rathburn, J. C., Valentine, G. H., Loegler, S. J., and Zarfos, D. E.: Citrullinuria, a new aminoaciduria associated with mental retardation. Lancet, $i$ : 138 (1962).

12. McMurray, W. C., Rathburn, J. C., Mohyaddin, F., and Kaegler, S. J.: Citrullinuria. Pediatrics, $32: 347$ (1963).

13. Morrow, G.: Citrullinemia. Amer. J. Dis. Child., 113: 157 (1967).

14. Nuzum, C. T., AND Snodgrass, P. J.: L'rea cycle enyzme adaptation to dietary protein in primates. Science, $172: 1042$ (1971).

15. Oberholzer, V. G., Levin, B., Burgess, E. A., and Young, W. F.: Methylmalonic aciduria: An inborn error of metabolism, leading to chronic metabolic acidosis. Arch. Dis. Childhood, 42: $492(1967)$.

16. Okken, A., de Groot, C. J., And Hommes, F. A.: Letter to the Editor. J. Pediat., $77: 164$ (1970).

17. RÄIHÄ, N. C. R., AND SUIKHONEN, J.: Development of urea synthesizing enzymes in human liver. Acta Paediat. Scand., 57: 121 (1968).

18. Ratner, S., Morell, H., and Carvalko, H.: Enzymes of arginine metabolism in brain. Arch. Biochem. Biophys., 91: 280 (1960).

19. Schneider, W. C.: Phosphorous compounds in animal tissues. I. Extraction and estimation of desoxypentose nucleic acid and of pentose nucleic acid. J. Biol. Chem., 161: 293 (1945).

20. Scott, C. R., Clarck, S., and Feny, C.: Nonketotic hyperglycinemia; evidence for an unidirectional defect in serine glycine interconversion. Pediat. Res., 3: 356 (1969).

21. Scott-Emuakpor, A., Higgins, J. V., ANd Kahrman, A. F.: 
Citrullinemia, a new case, with implications concerning adaptation to defective urea synthesis. Pediat. Res., 6: 626 (1972).

22. Tanaka, K., Budd, M. A., Efron, M. L., ANd Isselbacher, K. $\mathrm{J}$.: Isovaleric acidemia: A new genetic defect of leucine metabolism. Proc. Nat. Acad. Sci. U.S.A., 56: 236 (1966).

23. Tedesco, T. A., and Mellman, W. J.: Arginino succinate synthetase activity and citrullin metabolism in cells cultured from a citrullinemic subject. Proc. Nat. Acad. Sci. U.S.A., 57: 829 (1967).

24. Van der Zee, S. P. M., Trijbels, J. M. F., Monnens, L. A. H., Hommes, F. A., And Schretlen, E. D. A. M.: Citrullinemia in a newborn with rapid fatal course. Arch. Dis. Childhood, 46: 847 (1971).

25. Wick, H., BachmanN, C., Baumgarten, R., ANd BrechBüHLER, T.: Perakute Verlaufsnorm der Zitrullinämie mit
Tod im Neugeborencnalter. Helv. Pediat. Acta (Suppl. XXVII), 29 (1971).

26. Wick, H., Brechbühler, T., AND Girard, J.: Citrullinemia, elevated serum citrulline levels in healthy siblings. Experienta, 26: 823 (1970).

27. Beckman/Spinco, Palo Alto, Calif.

28. Flow Catalog no. 1-042D, Flow Labs, Rockville, Md.

29. Flow Catalog no. 1-019D, Flow Labs, Rockville, Md.

30. Purchased from the Radiochemical Centre, Amersham, Eng. land.

31. Nuclear Chicago Corporation, Des Plaines, Ill.

32. Requests for reprints should be addressed to: F. A. Hommes, Ph.D., Department of Pediatrics, Laboratory of Developmental Biochemistry, 10 Bloemsingel, Groningen, the Netherlands.

33. Accepted for publication June 7, 1973. 